\title{
Synthesis of optically pure ant pheromones with high enantiomeric purity.
}

\author{
Selim AI, Baren MH, Noser AA* \\ Chemistry Department, Faculty of Science, Tanta University, 31527, Egypt
}

\begin{abstract}
Chemical ecology studies with insects have founded that pheromonal communications often includes several components which can be linear, cyclic or heterocyclic compounds, in the case of chiral pheromones, insect often show the ability to characterize between and respond differently to stereoisomer. Among the most notable are those cases in which differential interspecific responses to enantiomer serve as a species isolating mechanism, the relationship between stereoisomers and pheromone activity are highly specific, meaningful assays and evaluation of the responses of insect to chiral pheromones must be carried out using substances of the highest possible chiral purity, we prepare ant pheromones using poly methyl methacrylate as chiral auxiliaries with high enantiomeric purity and the prepared compounds were characterized with spectroscopic data and the diastereomeric amides were separated using high performance liquid chromatography and give high enantiomeric excess, also we study the biological applications of our products and give agood results.
\end{abstract}

Keywords: Pheromones, enantiomer, stereoisomer, chiral purity, enantiomeric purity.

Accepted on December 21, 2017

\section{Introduction}

The fundamental basis of asymmetric synthesis is the creation of asymmetric centers such that the resulting enantiomers or diastereomers are formed in unequal proportions. This is achieved by the creation of new asymmetric centers either in a chiral molecule, through the use of asymmetric reagents or catalysts, or in molecules already possessing asymmetric centers, which generally influence the formation of new diastereomers in unequal amounts. It should be mentioned that the formation of chiral carbon compounds is by far the most widely investigated of asymmetric syntheses. However, similar approaches have been employed for the synthesis of chiral centers at sulfur, phosphorus and other elements [1]. Over the last few decades there has been much interest in the development of polymersupported chiral auxiliaries as an expedient and clean method for producing libraries of chiral compounds [2]. The major benefit of this approach is rapid and simplified purification of reaction by filtration, allowing for simple isolation of the desired chiral products and facile recovery of the polymersupported auxiliaries [3]. A number of polymer- supported auxiliaries have been developed for asymmetric synthesis, with recent examples using auxiliaries derived from ephedrine $[4,5]$, pseudo ephedrine [6], sugars [7,8], hydrobenzoin $[9,10]$, sulfoxide and sulfinamides [11], sulfoximine [12], naphthamide [13], hydroxyl pyrolidinone [14], imidazolidinone [15], and hydrazones [16]. Poly methylmethacrylate used as a good source to make steric hinderence to form enantiomeric excess 2-methy butanoic acid wich help us to form enantiomeric excess ant pheromones.

\section{Materials and Methods}

MMA monomer was purchased from fluka, lithium aluminum hydride used for reduction of polymethymethacrylate was purchased from Sigma, butanoic acid used for esterification was purchased from Fluka, n-butyl lithium and cyclohexyl isopropyl amine used in deprotonation step were purchased from Fluka, methyliodide used for the synthesis of polymeric ester was purchased from Sigma, Para-toluene sulphonic acid was purchased from Sigma, triethylamine was purchased from Fluka, ethyl acetate and petroleum ether [High Performance Liquid Chromatography analytical (HPLC) grade, Fisher], benzene (BDH Laboratory), Freshly distilled water was used for the preparation of all our products. The elemental analyses of compounds were performed at the micro analytical center, Cairo University using Perkin-Elmer $240 \mathrm{CHN}$ Elemental analyzer, The 1H NMR, 13C NMR spectra were recorded on a Bruker AC spectrometer (400 $\mathrm{MHz}$ ) at $25^{\circ} \mathrm{C}$ in DMSO-d6 with TMS as an internal standard at kafr el-shekh university, FT-IR absorption spectra were recorded on a Perkin Elmer 1422 spectro-photometer by central laboratory at Tanta university, and the spectra were carried out by using $\mathrm{KBr}$ disc technique, the samples were dried in oven then mounted on a sample holder with a large cavity, a smooth surface was obtained by pressing the powder samples with a glass paste. The separation of diastereomers were performed by using HPLC technique at micro analytical center at Cairo university.

\section{Experimental Part}

\section{Synthesis of methylmethacrylate linear polymer}

In a $250 \mathrm{ml}$ two neck round bottom flask, 30ml, $28.26 \mathrm{~g} \mathrm{(282}$ mmol) of Methylmethacrylate, $0.5 \mathrm{~g}$ of benzoyl peroxide, 100 $\mathrm{ml}$ of benzene were refluxed in a water bath for $5 \mathrm{hrs}$ under $\mathrm{N}_{2}$-gas, then the formed polymer was precipitated by petroleum ether, filterated off, dried under vacuum to give $27 \mathrm{~g}$ of dried methylmethacrylate linear polymer $(95.54 \%$ yield $)$. IR (KBr) v: $1725(\mathrm{C}=\mathrm{O}), 2920$ (aliph-H). 


\section{Reduction of methyl methacrylate linear polymer}

In a $250 \mathrm{ml}$ two neck round bottom flask $(10 \mathrm{~g}, 100 \mathrm{mmol})$ of Methylmethacrylate linear polymer(1) was dissolved in 40 $\mathrm{ml}$ dry dioxane then $(10 \mathrm{~g}, 263 \mathrm{mmol})$ of LiAlH4 was added slowly then the reaction mixture was refluxed for two days under $\mathrm{N}_{2}$-gas , after destroying the excess of $\mathrm{LiAlH}_{4}$ with $(263$ mmol of water, $263 \mathrm{mmol}$ of sodium hydroxide, dissolved in $789.47 \mathrm{mmol}$ of water), the beads were filterated off, washed with dilute $\mathrm{HCl}$, water, dried under vacuum to give $7 \mathrm{~g}$ of dried reduced Methylmethacrylate linear polymer (2) (97.22\% yield). IR (KBr) v: 3400(OH), 30532920 (aliph-H).

\section{Synthesis of linear polymeric asymmetric reagent}

In a $100 \mathrm{ml}$ two neck round bottom flask $(5 \mathrm{~g}, 69.4 \mathrm{mmol})$ of reduced Methylmethacrylate linear polymer (2) was dissolved in $30 \mathrm{ml}$ benzene then $(13 \mathrm{ml}, 12.53 \mathrm{~g}, 142.3 \mathrm{mmol})$ of butanoic acid was added and $0.5 \mathrm{~g}$ of $\mathrm{p}$-toluene sulphonic acid was added, the reaction mixture was refluxed for $5 \mathrm{hrs}$ under $\mathrm{N}_{2}$-gas using dean stark trap. Then the product was cooled and neutralized by $5 \%$ sodium carbonate solution. The linear polymeric asymmetric reagent was filterated off, dried to give $8.5 \mathrm{~g}(86.2 \%)$. IR (KBr) v: $1715(\mathrm{C}=\mathrm{O}), 2996$ (aliph-H).

\section{Synthesis of linear polymeric a-alkylated ester}

In a $100 \mathrm{ml}$ two neck round bottom flask ( $5 \mathrm{~g}, 35.2 \mathrm{mmole})$ of polymeric asymmetric reagent (3) was dissolved in $20 \mathrm{ml} \mathrm{THF}$, then $(10.2 \mathrm{ml}, 59.84 \mathrm{mmole})$ of cyclohexyl isopropylamine (CHIPA) was added at $-96^{\circ} \mathrm{C}$ (using methanol and liquid nitrogen) as cooling bath and at $-80^{\circ} \mathrm{C}$ (using acetone and liquid nitrogen) and at $-63^{\circ} \mathrm{C}$ (using chloroform and liquid nitrogen) then (4.928 ml, 59.84 mmole) of n-BuLi was added drop wise then the reaction mixture was stirred for 60 minutes under $\mathrm{N}_{2}$ gas , then $1 \mathrm{ml}$ of tetra methyl ethylenediamine (TMEDA) was added as catalyst and finally (70.4 mmole) of methyl iodide was added drop wise at $-40^{\circ} \mathrm{C}$, then the reaction mixture was stirred overnight. The product was filterated off, dried under vacuum to give $4.8 \mathrm{~g}(88.3 \%)$ yield. IR $(\mathrm{KBr}) \mathrm{v}: 1715(\mathrm{C}=\mathrm{O}), 2996$ (aliph-H).

\section{Synthesis of (S)-2-methyl butanoic acid}

In a $100 \mathrm{ml}$ round bottom flask ( $5 \mathrm{~g}, 32 \mathrm{mmole})$ of linear polymeric $\alpha$-alkylated ester (4) was dissolved in $20 \mathrm{ml}$ dioxane, then (0.5 g, $2.97 \mathrm{mmole})$ of p-toluene sulphonic acid was added, the reaction mixture was refluxed for $12 \mathrm{hrs}$ under $\mathrm{N}_{2}$ gas [TLC-control; eluent, petroleum ether : ethyl, acetate $8: 2, \mathrm{I}_{2}$ vapor] then pour the reaction mixture in ice water, the reduced polymer was filtrated off to give $(2.15 \mathrm{~g})$ and the 2-alkylated acid (2-methyl butanoic acid) was extracted by $20 \mathrm{ml}$ methylene chloride, dried by anhydrous sodium sulphate to give $3 \mathrm{ml}$ of pale yellow liquid (85.88\% yield). 1H NMR (DMSO) $\delta: 9.5$ (s, exch., 1H, $\mathrm{COOH}$ ), 1.0 (t, exch., $3 \mathrm{H}, \mathrm{CH}_{3}$ ), 1.3 (d, exch., $3 \mathrm{H}, \mathrm{CH}_{3}$ ), 1.5 (m, exch., 2H, $\left.\mathrm{CH}_{2}\right), 2.7$ (m, exch., 1H, C-H). IR (KBr) v: $3415(\mathrm{OH}), 1725(\mathrm{C}=\mathrm{O}), 2996$ (aliph-H).

\section{Synthesis of diastereomeric amides of 2-methyl butanoic acid}

In $100 \mathrm{ml}$ round bottom flask dissolve $(1.5 \mathrm{~g}, 11 \mathrm{mmole})$ of amine [(R)-phenyl glycinol] in $(1.11 \mathrm{~g}, 1.53 \mathrm{ml}, 11 \mathrm{mmole})$ of triethyl amine and $10 \mathrm{ml} \mathrm{THF}$, cool (ice bath), then $(1.5 \mathrm{ml}$, 13 mmole) (S) 2-methyl butanoyl chloride was added drop wise, then the liquid mixture was refluxed for 5-6 hrs [TLCcontrol; eluent, petroleum ether : ethyl acetate $8: 2, \operatorname{tR}(s)=0.65$, $\mathrm{tR}(\mathrm{p})=0.68$, I2 vapor], then the diastereomeric amides were extracted with $20 \mathrm{ml}$ methylene chloride, washed with $1 \mathrm{~N} \mathrm{HCl}$ then $1 \mathrm{~N} \mathrm{NaOH}$, dried over sodium sulphate an hydrous and filterated off to give $(1.8 \mathrm{~g})$ of yellow liquid $(81.44 \%$ yield $)$.

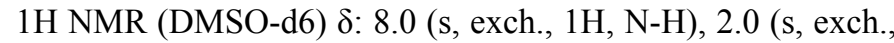
1H, OH), 7.08-7.42 (m, 5H, Ar-H), 0.96 (t, exch., 3H, $\mathrm{CH}_{3}$ ), 1.24 (d, exch., 3H, $\left.\mathrm{CH}_{3}\right), 1.57$ (m, exch., $\left.2 \mathrm{H}, \mathrm{CH}_{2}\right), 2.6(\mathrm{~m}$, exch., 1H, C-H), 4.2 (d, exch., 2H, $\mathrm{CH}_{2}$ ), 4.9 (t, exch., 1H, C-H). IR (KBr) v: $3415(\mathrm{OH}), 3369(\mathrm{~N}-\mathrm{H}), 3020(\mathrm{Ar}-\mathrm{H}), 2996$ (aliph-H), Anal. Calcd for $\mathrm{C}_{13} \mathrm{H}_{19} \mathrm{O}_{2} \mathrm{~N}(221): \mathrm{C}, 70.58 \% ; \mathrm{H}$, $8.59 \%$; N,6.33\%. found: C, 70.36\% ; H, 8.34\% ; N, 6.19\%].

Separation of the two diastereomeric amides of 2- methyl butanoic acid using HPLC with silica gel column: The two diastereomeric amides (6) were dissolved in methylene chloride and separated by HPLC using silica gel column, eluents : petroleumether : ethylacetate $8: 2$, flow rate $=1 \mathrm{ml} / \mathrm{min}$, detector :UV $254 \mathrm{~nm}, \mathrm{TR} 1=1.35 \mathrm{~min}, \mathrm{TR} 2=2.11 \mathrm{~min}$.

\section{Synthesis of (S) 4-methyl-3-hexanone}

In a $100 \mathrm{ml}$ two neck round bottom flask $2.15 \mathrm{ml}$ (59.84 mmole) of EtLi was added to (5.84 g,48.7 mmole) of (S) 2-methyl butanoyl chloride at $-80^{\circ} \mathrm{C}$ under $\mathrm{N} 2$-gas followed by stirring overnight, then the product was extracted with methylene chloride.1H NMR (DMSO) $\delta: 0.96$ (t, exch., 6H, 2 $\mathrm{CH}_{3}$ ), 1.2 (d, exch., 3H, $\mathrm{CH}_{3}$ ), 1.5 (m, exch., $\left.2 \mathrm{H}, \mathrm{CH}_{2}\right), 2.4$ (m, exch., $2 \mathrm{H}$, $\mathrm{CH}_{2}$ ), 2.7 (m, exch., 1H, C-H), IR (KBr) v: $1650(\mathrm{C}=\mathrm{O}), 2996$ (aliph-H). 13C (DMSO) $\delta: 10,12,21 \mathrm{ppm}\left(3 \mathrm{CH}_{3}\right), 30,38 \mathrm{ppm}$ $\left(2 \mathrm{CH}_{2}\right), 40 \mathrm{ppm}(1 \mathrm{CH})$ and finally at $195 \mathrm{ppm}(\mathrm{C}=\mathrm{O})$.

\section{Synthesis of (S) 4-methyl-3-hexanol (ant pheromone)}

Fermentation (step 1): $39 \mathrm{ml}$ mole (13.3 g) of sucrose was added to $0.6 \mathrm{ml}$ mole $(0.041 \mathrm{~g})$ of sodium hydrogen phosphate then dissolved in $25 \mathrm{ml}$ warm water followed by addition of $2.6 \mathrm{~g}$ of yeast, the reaction mixture was heated at $40^{\circ} \mathrm{C}$ for $1 \mathrm{hr}$ under $\mathrm{N}_{2}$-gas and finally the product was cooled.

Stereo selective reduction (Step 2): 7.3 mmole $(0.83 \mathrm{ml})$ of (S) 4-Methyl-3-hexanone was added to the fermented product and stirred vigorously at room temperature for three days, then the product was filtered and extracted with methylene chloride.

1H NMR (DMSO) $\delta: 0.96$ (t, exch., 6H, 2CH $), 1.04$ (d, exch., $\left.3 \mathrm{H}, \mathrm{CH}_{3}\right), 1.2$ (m, exch., $\left.2 \mathrm{H}, \mathrm{CH}_{2}\right), 1.3\left(\mathrm{~m}\right.$, exch., $\left.2 \mathrm{H}, \mathrm{CH}_{2}\right), 1.4$ (m, exch., 1H, C-H), 2 (s, exch., 1H, OH), 3.2 (m, exch., 1H, $\mathrm{C}-\mathrm{H})$, IR (KBr) v: $3480(\mathrm{OH}), 2996$ (aliph-H). 13C (DMSO) $\delta$ : $11,13,21 \mathrm{ppm}\left(3 \mathrm{CH}_{3}\right), 25,31 \mathrm{ppm}\left(2 \mathrm{CH}_{2}\right)$, and finally at 39 , $68 \mathrm{ppm}(2 \mathrm{CH})$.

\section{Results and Discussion}

Asymmetric alkylation reactions using polymer-supported chiral auxiliaries have not been widely investigated yet [17]. In this field, solid supported chiral auxiliaries such as Evans'2oxazolidinones [18] and pseudoephedrines [19-29] have been mainly explored. In this research we make modification of poly methylmethacrylate resins which facilitated the synthesis of 2-methyl butanoic acid in a good stereoselectivity. 
The reduction of PMMA beads were carried out by treatment with $\mathrm{LiAlH}_{4}$ in dioxane as solvent. The conversion of the ester group was followed by the IR spectra, which showed the $\mathrm{OH}$ stretching at $3400 \mathrm{~cm}^{-1}$ and a complete loss of the $\mathrm{C}=\mathrm{O}$ stretching. The conversion was also obtained quantitatively by further chemical modification through esterification by treatment of polymeric alcohol by butanoic acid in presence of methanesulphonic acid and benzene as solvent using dean stark trap (Figure 1). The IR spectra of the polymeric asymmetric reagent indicate the reappearance of $\mathrm{C}=\mathrm{O}$ stretching at 1715 $\mathrm{cm}^{-1}$ and a complete disappearances of $\mathrm{OH}$ stretching.

The deprotonation step takes place by the addition of $\mathrm{Li}$ CHIPA to polymeric asymmetric reagents at $-96^{\circ} \mathrm{C}$ followed by alkylation using methyl iodide in the presence of TMEDA as catalyst lead to formation of polymeric enantiomerically excess $\alpha$-alkylated ester. The IR spectra of the product showed the absorption at $2996 \mathrm{~cm}^{-1}$ which is characteristic for $\left(\mathrm{CH}_{2}\right.$ chain $)$, and at $1715 \mathrm{~cm}^{-1}$ which is characteristic for $\mathrm{C}=\mathrm{O}$ group. The hydrolysis of this product by Para-toluene sulphonic acid leads to formation of enantiomerically excess (S) 2-methyl butanoic acid (Figure 2). The FT-IR spectra of the product showed the absorption at $1725 \mathrm{~cm}^{-1}$ which is characterized for $\mathrm{C}=\mathrm{O}$ group, and at $3415 \mathrm{~cm}^{-1}$ which is characterized for $\mathrm{OH}$ group and at $2996 \mathrm{~cm}^{-1}$ which is characterized for C-H aliphatic .

The $1 \mathrm{H}-\mathrm{NMR}$ spectrum of compound 5 is characterized by the appearance of singlet signal resonated at $9.5 \mathrm{ppm}(1 \mathrm{H})$ attributed to $\mathrm{COOH}$ proton, the appearance of triplet signal resonated at $1.0 \mathrm{ppm}(3 \mathrm{H})$ attributed to $\mathrm{CH}_{3}-\mathrm{CH}_{2}$ proton, the appearance of douplet signal resonated at $1.3 \mathrm{ppm}(3 \mathrm{H})$ attributed to $\mathrm{CH}_{3}-\mathrm{CH}$ proton the appearance of multiplet signal resonated at $1.5 \mathrm{ppm}$ $(2 \mathrm{H})$ attributed to $\mathrm{CH}_{2}$ proton, and finally the appearance of multiplet signal resonated at $2.7 \mathrm{ppm}(1 \mathrm{H})$ attributed to $\mathrm{C}-\mathrm{H}$ proton.

The treatment of this acid by thionyl chloride leads to the formation of (S) 2-methyl butanoyl chloride which added to phenyl glycinol to form diastereomeric amides (Figure 3) elemental analysis [calculated for $\mathrm{C}_{13} \mathrm{H}_{19} \mathrm{O}_{2} \mathrm{~N}(221)$ : C,70.58\%; $\mathrm{H}, 8.59 \%$; N,6.33\%. found: C, 70.36\%; H, 8.34\%; N, 6.19\%].

The FT-IR spectra of the product showed the absorption at $1750 \mathrm{~cm}^{-1}$ which is characterized for $\mathrm{C}=\mathrm{O}$ group, and at $3415 \mathrm{~cm}^{-1}$ which is characterized for $\mathrm{OH}$ group, and at 3369 $\mathrm{cm}^{-1}$ which is characterized for $\mathrm{NH}$ group, and at $2996 \mathrm{~cm}^{-1}$ which is characterized for $\mathrm{C}-\mathrm{H}$ aliphatic, at $3020 \mathrm{~cm}^{-1}$ which is characterized for $\mathrm{C}-\mathrm{H}$ aromatic and at $715 \mathrm{~cm}^{-1}$ which is characterized for five adjacent proton in benzene ring (mono substituted benzene).

The 1H-NMR spectrum of compound is characterized by the appearance of triplet signal resonated at $0.96 \mathrm{ppm}(3 \mathrm{H})$ due to $\mathrm{CH}_{3}$ proton, the appearance of douplet signal resonated at 1.24 ppm $(3 \mathrm{H})$ attributed to $\mathrm{CH}_{3}$ proton, the appearance of multiplet signal resonated at $1.57 \mathrm{ppm}(2 \mathrm{H})$ attributed to $\mathrm{CH}_{2}$ proton, the appearance of singlet signal resonated at $2.0 \mathrm{ppm}(1 \mathrm{H})$ attributed to $\mathrm{OH}$ proton which disappear by addition of $\mathrm{D}_{2} \mathrm{O}$, the appearance of multiplet signal resonated at $2.6 \mathrm{ppm}(1 \mathrm{H})$ attributed to $\mathrm{C}-\mathrm{H}$ proton, the appearance of douplet signal resonated at $4.20 \mathrm{ppm}$ $(2 \mathrm{H})$ attributed to $\mathrm{CH}_{2}$ proton, the appearance of triplet signal resonated at $4.96 \mathrm{ppm}(1 \mathrm{H})$ attributed to $\mathrm{C}-\mathrm{H}$ proton, while the proton due to phenyl group $(5 \mathrm{H})$ resonated as multiplet in<smiles>CCCCCCCC(C)(C)C(=O)OC</smiles>

Methylmethacrylate

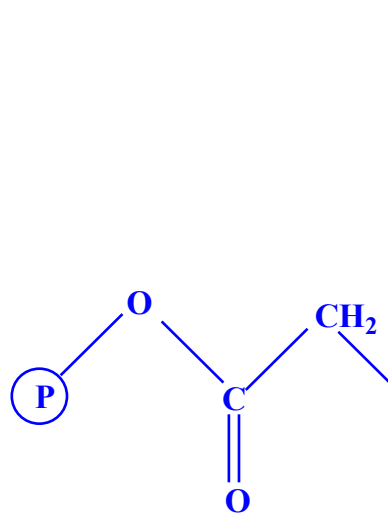

linear polymeric asymmetric reagent

(3) poly methylmethacrylate

(1)
$\mathrm{LiAlH}_{4}$ dioxane

$\mathrm{CH}_{3}$<smiles>CCC(C)(C)CO</smiles>

reduced poly methylmethacrylate

Figure 1: Synthesis of linear polymeric asymmetric reagent. 
Citation: Selim AI, Baren MH, Noser AA. Synthesis of optically pure ant pheromones with high enantiomeric purity. Environ Risk Assess Remediat. 2017;2(1):21-27<smiles>[C+]OC(=O)CC</smiles>

linear polymeric asymmetric reagent

(3)

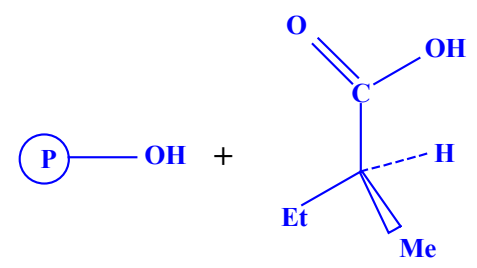

(S) form
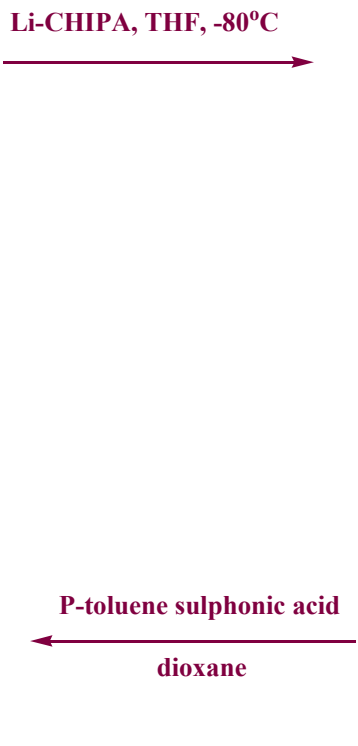

(5)
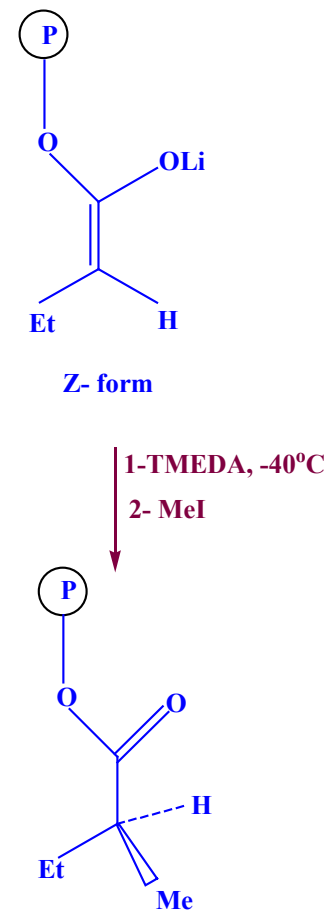

(S) form

Figure 2: Synthesis of 2-methyl butanoic acid from polymeric ester.<smiles>CCC(C)C(=O)O</smiles>

5
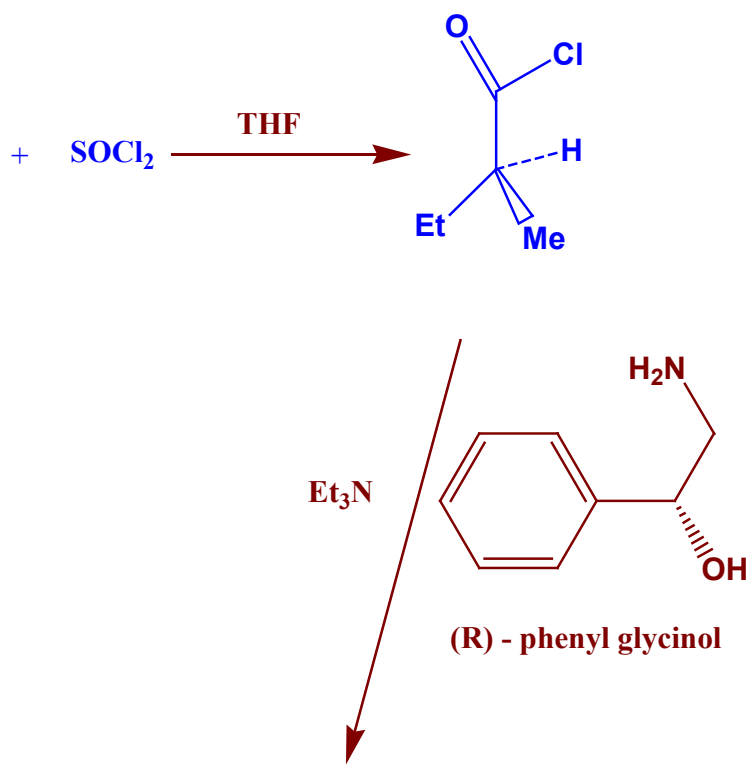<smiles>CCC(C)C(=O)NC(C)(C)CO</smiles>

6

Figure 3: Synthesis of diastereomeric amides of 2-methyl butanoic acid. 
the 7.08-7.42 ppm region, and finally the appearance of singlet signal resonated at $8.0 \mathrm{ppm}(1 \mathrm{H})$ attributed to $\mathrm{NH}$ proton which disappear by addition of $\mathrm{D}_{2} \mathrm{O}$.

These diastereomeric amides were separated using HPLC with silica gel column (Figure 4) to give S Configuration with $82 \%$ Enantiomeric Excess.

Also, the treatment of acid chloride with ethyl lithium at $-80^{\circ} \mathrm{C}$ in THF as solvent leads to formation of (S) 4-Methyl-3-hexanone. The IR spectra of compound 7 indicate the appearance of the $\mathrm{C}=\mathrm{O}$ stretching at $1650 \mathrm{~cm}^{-1}$ and disappearances of the $\mathrm{OH}$ stretching. The $1 \mathrm{H}-\mathrm{NMR}$ spectrum of compound 7 is characterized by the appearance of triplet signal resonated at $0.96 \mathrm{ppm}(6 \mathrm{H})$ due to two $\mathrm{CH}_{3}-\mathrm{CH}_{2}$ proton, the appearance of douplet signal resonated at $1.2 \mathrm{ppm}(3 \mathrm{H})$ attributed to $\mathrm{CH}_{3}-$ $\mathrm{CH}$ proton, the appearance of multiplet signal resonated at 1.5 ppm $(2 \mathrm{H})$ attributed to $\mathrm{CH}_{2}$ proton, the appearance of multiplet signal resonated at $2.4 \mathrm{ppm}(2 \mathrm{H})$ attributed to $\mathrm{CH}_{2}-\mathrm{CO}$ proton, and finally the appearance of multiplet signal resonated at 2.7 ppm $(1 \mathrm{H})$ attributed to $\mathrm{C}-\mathrm{H}$ proton.

The 13C indicate the presence of different types of carbon atoms, at 10, 12, $21 \mathrm{ppm}\left(3 \mathrm{CH}_{3}\right), 30,38 \mathrm{ppm}\left(2 \mathrm{CH}_{2}\right), 40 \mathrm{ppm}$ $(1 \mathrm{CH})$ and finally at $195 \mathrm{ppm}(\mathrm{C}=\mathrm{O})$.

Further chemical modification of (S) 4-Methyl-3-hexanone through stereoselective reduction with Baker's yeast leads to formation of (S) 4-Methyl-3-hexanol (ant pheromone) (Figure 5). The IR spectra of compound indicate the reappearance of $\mathrm{OH}$ stretching at $3480 \mathrm{~cm}^{-1}$ and disappearances of $\mathrm{C}=\mathrm{O}$ stretching. The 1H-NMR spectrum of compound is characterized by the appearance of triplet signal resonated at $0.96 \mathrm{ppm}(6 \mathrm{H})$ due to two $\mathrm{CH}_{3}-\mathrm{CH}_{2}$ proton, the appearance of douplet signal resonated at $1.04 \mathrm{ppm}(3 \mathrm{H})$ attributed to $\mathrm{CH}_{3}-\mathrm{CH}$ proton, the appearance of multiplet signal resonated at $1.2 \mathrm{ppm}(2 \mathrm{H})$ attributed to $\mathrm{CH}_{2}$ proton, the appearance of multiplet signal resonated at $1.3 \mathrm{ppm}$ $(2 \mathrm{H})$ attributed to $\mathrm{CH}_{2}$ proton, the appearance of multiplet signal resonated at $1.45 \mathrm{ppm}(1 \mathrm{H})$ attributed to $\mathrm{CH}-\mathrm{CH}_{3}$ proton, the appearance of singlet signal resonated at $2 \mathrm{ppm}(1 \mathrm{H})$ attributed to $\mathrm{OH}$ proton, and finally the appearance of multiplet signal resonated at $3.25 \mathrm{ppm}(1 \mathrm{H})$ attributed to $\mathrm{CH}-\mathrm{O}$ proton.

The $\mathrm{C}_{13}$ indicate the presence of different types of carbon atoms, at $11,13,21 \mathrm{ppm}\left(3 \mathrm{CH}_{3}\right), 25,31 \mathrm{ppm}\left(\mathrm{CH}_{2}\right)$, and finally at 39 , 68 ppm $(2 \mathrm{CH})$.

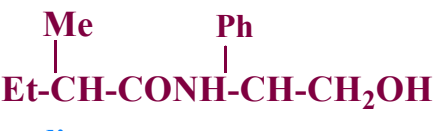

diastereomers

(6)

HPLC separation using silica gel column

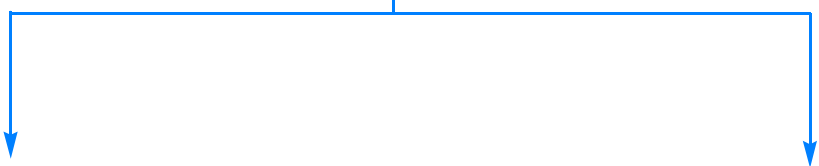<smiles>CC[C@H](C)C(=O)NC(CO)c1ccccc1</smiles>

$(\mathbf{S}, \mathbf{R})$

$$
\begin{gathered}
12 \mathrm{~N} \mathrm{H}_{2} \mathrm{SO}_{4} \\
\text { dioxane }
\end{gathered}
$$<smiles>CC[C@H](C)C(=O)O</smiles>

(S) isomer<smiles>C=C(NC(=O)[C@@H](C)CC)c1ccccc1</smiles>

$(\mathbf{R}, \mathbf{R})$

$12 \mathrm{~N} \mathrm{H}_{2} \mathrm{SO}_{4}$

dioxane

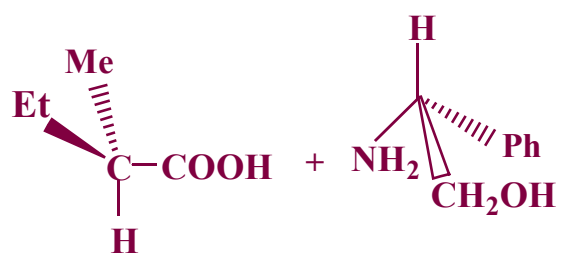

$(\mathrm{R})$ isomer

Figure 4: General scheme for separation of two diastereomeric amides. 


\section{Applications}

\section{In vitro anti-proliferative activity}

Cytotoxicity was expressed as the concentration that caused $50 \%$ loss of the cell monolayer (IC50). Doxocubicin as a standard anticancer drug was used for comparison, the (S) 4-methyl-3hexanone was selected to be screened for its anticancer activity in vitro against four representative cell lines of HePG-2, MCF7, HCT-116, and PC-3 (Figure 6). From the obtained results, it was obvious that the tested compound displayed excellent, moderate anti-proliferative activity against the tested cell lines as we see in Table 1 and Figure 1.

\section{Anti-oxidant activity screening}

The antioxidant activities of (S) 4-methyl-3-hexanone was evaluated, The data showed that compound showed strong activity to inhibit oxidation and weak inhibitory activity in the hemolysis assay as we see in Tables 2 and 3.

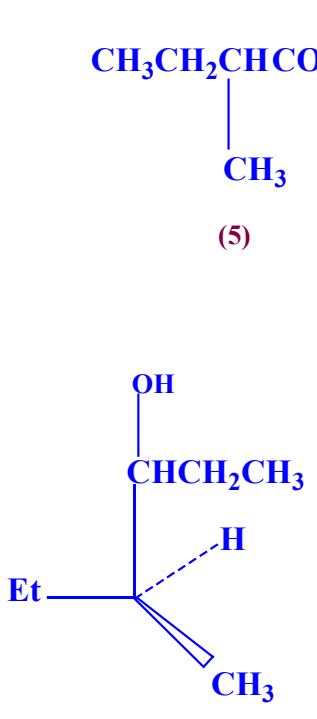

(S) 4-Methyl-3-hexanol

(8)<smiles>CCC(C)C(=O)Cl</smiles>

Et Li , THF, $-80^{\circ} \mathrm{C}$

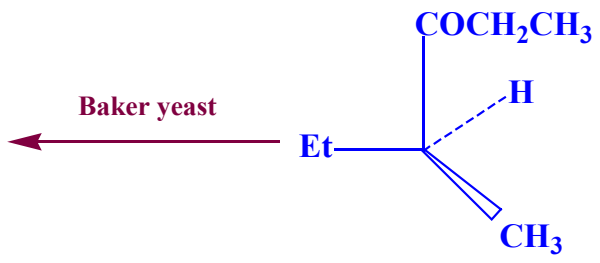

(S) 4-Methyl-3-hexanone

(7)

Figure 5: synthesis of (S) -4-Methyl-3-hexanone and (S) 4-Methyl-3-hexanol.

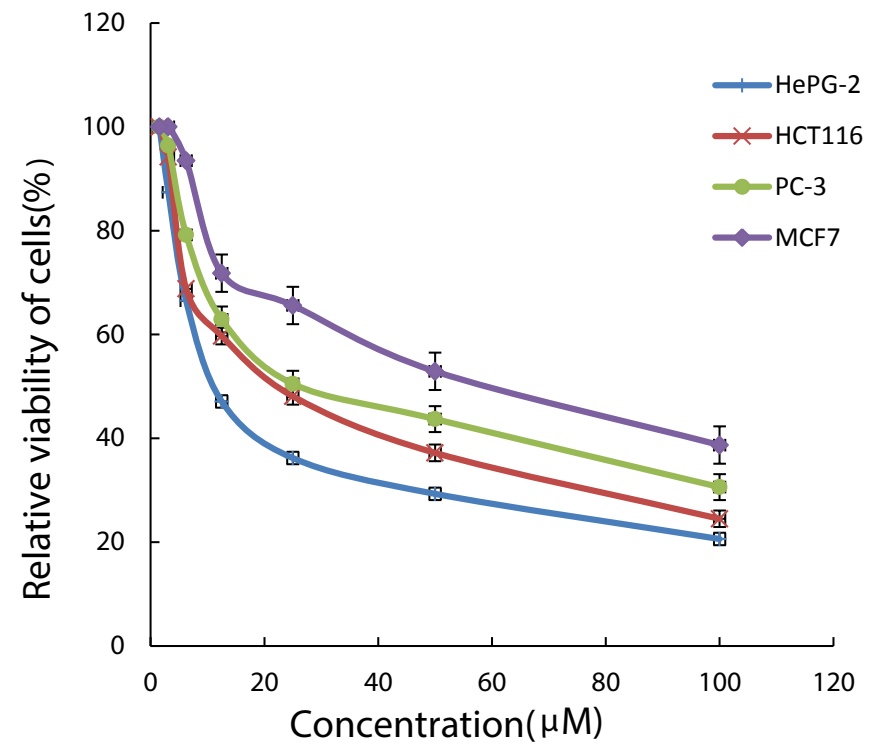

Figure 6: Cytotoxic activity of compound 8 against human tumor cells. 
Table1: Cytotoxic activity of compound 7 against human tumor cells.

\begin{tabular}{|c|c|c|c|c|}
\hline \multirow{2}{*}{ Compounds } & \multicolumn{4}{|c|}{ In vitro Cytotoxicity IC50 $(\boldsymbol{\mu M})$} \\
\cline { 2 - 5 } & HePG2 & HCT-116 & PC3 & MCF-7 \\
\hline DOX & $4.50 \pm 0.3$ & $5.23 \pm 0.2$ & $8.87 \pm 0.6$ & $4.17 \pm 0.2$ \\
\hline 8 & $15.42 \pm 1.2$ & $24.02 \pm 1.6$ & $31.87 \pm 2.5$ & $54.82 \pm 3.6$ \\
\hline
\end{tabular}

IC50 ( $\mu \mathrm{M}): 1-10$ (very strong).

$11-20$ (strong).

$21-50$ (moderate).

$51-100$ (weak) and above 100 (non-cytotoxic)

$\mathrm{DOX}=$ Doxorubicin

Table 2: Anti-hemolytic Assay.

\begin{tabular}{|c|c|c|c|}
\hline \multirow{3}{*}{ No. } & \multirow{3}{*}{ Compounds } & \multirow{2}{*}{\multicolumn{2}{|c|}{$\begin{array}{c}\text { Erythrocyte hemolysis } \\
\text { A/B x } 100\end{array}$}} \\
\hline & & & \\
\hline & & $\begin{array}{l}\text { Absorbance of } \\
\text { samples (A) }\end{array}$ & $\%$ hemolysis \\
\hline \multicolumn{2}{|c|}{ Absorbance of $\mathrm{H}_{2} \mathrm{O}(\mathrm{B})$} & 0.865 & -- \\
\hline \multicolumn{2}{|c|}{ Vit - C } & 0.035 & $4.00 \%$ \\
\hline 1 & 8 & 0.026 & $3.00 \%$ \\
\hline
\end{tabular}

Table 3: Anti-Oxidant Assays.

\begin{tabular}{|c|c|c|c|}
\hline No. & Method & $\begin{array}{c}\text { ABTS Abs(control)-Abs(test) } \\
\text { Abs(control)X100 }\end{array}$ & \\
\hline & Compounds & Absorbance of samples & $\%$ inhibition \\
\hline & Control of ABTS & 0.54 & $0 \%$ \\
\hline & Ascorbic-acid & 0.058 & $89.20 \%$ \\
\hline 1 & 8 & 0.417 & $22.80 \%$ \\
\hline
\end{tabular}

\section{Conclusion}

In summary, an efficient synthesis of S-4-Methyl-3-hexanone and S-4-Methyl-3-hexanol as ant pheromones with high enantiomeric purity using polymeric asymmetric reagent has been achieved and studying the biological applications of these products.

\section{References}

1. Selim A, Badawy M, Noser A. International Journal of Chemical and Applied Biological Sciences. 2014;1:135.

2. Chung CWY, Toy PH. Asymmetry. 2004;15:387.

3. Green R, Peed J, Taylor JE, et al. Nature protocols. 2013;8:1890.

4. Kerrigan NJ, Hutchison PC, Heightman TD, et al. Org Biomol Chem. 2004;2:2476.

5. El-Shehawy AA. Tetrahedron. 2007;63:5490.

6. McGhee AM, Kizirian JC, Procter DJ. Org Biomol Chem. 2007;5:1021.
7. Zech G, Kunz H. Chem Eur J. 2004;10:4136.

8. Kim HJ, Shin EK, Chang JY, et al. Tetrahedron Lett. $2005 ; 46: 4115$.

9. Schuster C, Knollmueller M, Gaertner P. Tetrahedron Asymmetry. 2005;16:3211.

10. Broeker J, Knollmueller M, Gaertner P. Tetrahedron Asymmetry. 2006;17:2413.

11. Senanayake $\mathrm{CH}$, Krishnamurthy $\mathrm{D}, \mathrm{Lu} \mathrm{ZH}$, et al. Aldrichimica Acta. 2005;38:93.

12. Gais HJ, Babu GS, Günter $M$ et al. Eur J Org Chem. 2004; $19: 1464$.

13. Zhang Y, Wang YQ, Dai WM. J Org Chem. 2006;71:2445.

14. Songis O, Geant PY, Sautrey G, et al. Eur J Org Chem. 2008; 14:308.

15. Lazny R, Nodzewska A. Chem Rev. 2009;110:1386.

16. Quynh PBN, Kim JN, Kim TH. Tetrahedron Lett. 2009;50:4015.

17. Turkyilmaz S, Wilcox CS. Tetrahedron Letters. 2017;58:2031.

18. Chung CWY, Toy PH. Tetrahedron: Asymmetry. 2004; $15: 387$.

19. Kotake T, Hayashi Y, Rajesh S, et al. Tetrahedron. $2005 ; 61: 3819$.

20. Green R, Merritt AT, Bull SD. Chem Commun. 2008;23:508.

21. Nguyen QPB, Kim JN, Kim TH. Tetrahedron Lett. 2009;50:4015.

22. Nguyen QPB, Kim THB. Korean Chem Soc. 2009;30:2935.

23. Hu FQ, Xia DX, Lu CF, et al. Eur J Org Chem. 2010;60:5552.

24. Broeker J, Knollmueller M, Gaertner P. Tetrahedron Asymmetry. 2009;20:273.

25. Hutchison PC, Heightman TD, Procter DJ. Org Lett. 2002;4:4583.

26. Lazny R, Nodzewska A, Zabicka BJ. Comb Chem. 2008;10:986.

27. Spino C, Gund VG, Nadeau CJ. Comb Chem. 2005;7:345.

28. Price MD, Kurth MJ, Schore NE. J Org Chem. 2002;67:7769.

29. Lu C, Hu L, Yang G, et al. Curr Org Chem. 2012;16:2802.

\section{*Correspondence to:}

Noser AA

Department of Chemistry

Tanta University

Tanta

31527

Egypt

Tel: 0201064556083

E-mail: Chemistnoser2010@yahoo.com 